\title{
KINERJA KEUANGAN SUB SEKTOR BUILDING CONSTRUCTION NON-BUMN SEBELUM DAN SETELAH PRIORITAS INFRASTRUKTUR
}

\author{
Ray Agung Sucika Pratama ${ }^{1}$ \\ Tony Irawan ${ }^{2}$ \\ Raden Dikky Indrawan ${ }^{3}$ \\ ${ }^{1}$ Sekolah Bisnis, Institut Pertanian Bogor \\ Email : pratama62@apps.sb.ac.id \\ ${ }^{2}$ Fakultas Ekonomi dan Manajemen, Institut Pertanian Bogor \\ Email : tonyirawan82@gmail.com \\ ${ }^{3}$ Sekolah Bisnis, Institut Pertanian Bogor \\ Email : rdikky@apps.ipb.ac.id
}

\begin{abstract}
Since 2014 the government has focused on developing national infrastructure as stated in Nawacita and as seen in the significant increase in the infrastructure budget from 2015-2019. However, the increase in the infrastructure budget did not affect the private building construction sub-sector companies' profit. This study aims to measure the financial performance of the private building construction sub-sector and to determine the significance of the differences between financial performance before and after infrastructure becomes the focus of development. Purposive sampling was used within the criteria of a private building construction sub-sector company that publishes annual financial reports for 2011-2019. The period is divided into two, before infrastructure becomes the focus of development (2011 - 2014) and after infrastructure becomes the focus of development (2015 - 2019). Paired sample t-test and financial ratio analysis (FRA) were used to analyze the data. The results show that return on assets and total asset turnover have a significant difference between the period before and after infrastructure becomes the focus of development, while the current ratio and debt to equity ratio are not significantly different. These findings can be useful for company managers who would continue to explore opportunities to provide higher profits.
\end{abstract}

Keywords: financial performance, construction, profitability, solvency

\section{PENDAHULUAN}

Industri jasa konstruksi merupakan salah satu sektor industri yang memiliki posisi yang strategis dalam sistem ekonomi nasional. Nilai strategisnya adalah keterkaitan antara sektor ini terhadap rantai pemasok (bahan baku, peralatan) dan pengguna, serta hasil produknya yang berfungsi sebagai sarana dan prasarana bagi bekerjanya sektor lainnya (Suraji et al., 2007). Sektor konstruksi berperan sebagai katalisator yang dapat memacu pertumbuhan beberapa sektor ekonomi lainnya (BPS, 2018). Industri konstruksi mempunyai peran penting bagi pertumbuhan ekonomi nasional sehingga perlu diperhatikan berbagai permasalahan yang sering terjadi yang dapat mengakibatkan penurunan kinerja perusahaan jasa konstruksi (Trianto, 2011).

Industri jasa konstruksi adalah industri yang mencakup semua pihak yang terkait dengan proses konstruksi termasuk tenaga profesi, pelaksana konstruksi dan juga para pemasok yang bersama-sama memenuhi kebutuhan pelaku dalam industri. Jasa konstruksi adalah jasa yang menghasilkan prasarana dan sarana fisik. Mengingat bahwa prasarana dan sarana fisik merupakan landasan pertumbuhan sektor-sektor dalam pembangunan nasional serta kenyataan bahwa jasa konstruksi juga berperan sebagai penyedia lapangan kerja, maka jasa konstruksi penting dalam pembangunan nasional (Jonudin et al., 2011). Melalui sektor inilah, secara fisik kemajuan pembangunan dapat dilihat langsung (Rachenjantono, 2008). Laju pertumbuhan sektor konstruksi di Indonesia yang terjadi dalam beberapa tahun ke belakang mengalami fluktuasi dari tahun ke tahun. Tabel 1 menunjukkan kontribusi terhadap PDB dan laju pertumbuhan sektor konstruksi tahun 2012-2019.

Tabel 1 Kontribusi sektor konstruksi terhadap PDB dan laju pertumbuhan tahun 2012-2020

\begin{tabular}{lccccccccc}
\hline \multicolumn{1}{c}{ Keterangan } & \multicolumn{10}{c}{ Tahun } \\
\cline { 2 - 10 } & 2012 & 2013 & 2014 & 2015 & 2016 & 2017 & 2018 & $2019 * *$ & $2020^{*}$ \\
\hline $\begin{array}{l}\text { Kontribusi sektor konstruksi } \\
\text { terhadap PDB (\%) }\end{array}$ & 10,45 & 9,99 & 10,05 & 10,21 & 10,38 & 10,37 & 10,53 & 10,60 & 10,70 \\
$\begin{array}{l}\text { Laju pertumbuhan rata-rata } \\
\text { sektor konstruksi (\%) }\end{array}$ & 7,5 & 6,57 & 6,6 & 6,6 & 5,22 & 6,79 & 6,09 & 5,75 & - \\
\hline
\end{tabular}

Sumber: diolah dari Badan Pusat Statistik (2012-2020)

**data triwulan III, *data triwulan 
Sejak pergantian presiden yang dimenangkan oleh Joko Widodo (Jokowi) sebagai presiden dan Jusuf Kalla sebagai wakil presiden untuk masa bakti 2014 - 2019, pemerintah telah memberikan banyak perhatian dan kebijakan terhadap pembangunan infrastruktur nasional. Hal ini tertuang dalam sembilan program prioritas pembangunan nasional (Nawacita) yang memprioritaskan percepatan pembangunan infrastruktur untuk menghubungkan pinggiran dengan pusat pertumbuhan, dan mempromosikan konektivitas antar pulau di kepulauan (BPIW, 2016). Berdasarkan data anggaran infrastruktur tahun 2011 hingga tahun 2019 (Gambar 1), anggaran infrastruktur mengalami peningkatan setiap tahunnya. Kenaikan realisasi anggaran infrastruktur tersebut disebabkan oleh pembangunan infrastruktur telah menjadi prioritas utama dalam pembangunan nasional (Setjen DPR RI, 2015). Terpenuhinya rencana pembangunan infrastruktur tentunya melibatkan peranan penting industri jasa konstruksi di Indonesia. Gencarnya pembangunan infrastruktur di Indonesia menjadi salah satu faktor meningkatnya peran sektor konstruksi terhadap perekonomian Indonesia (BPS, 2018).

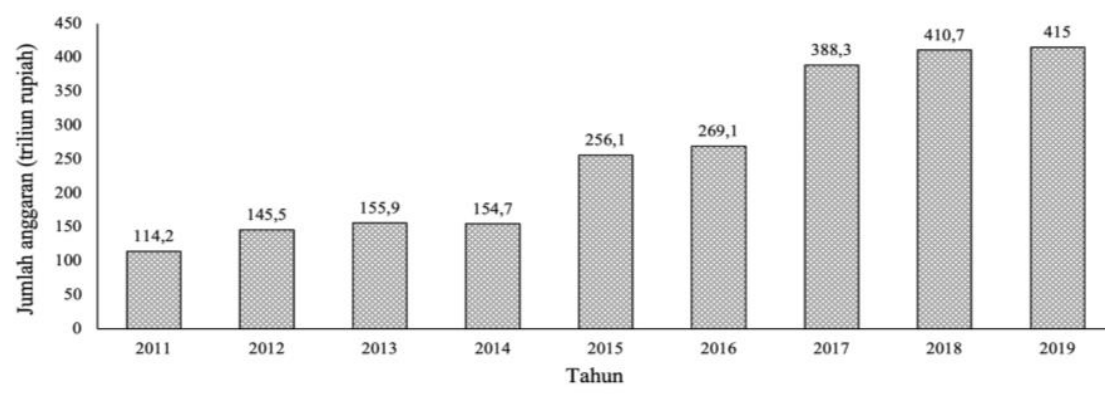

Gambar 1. Anggaran infrastruktur tahun 2011-2019 (Kemenkeu 2019)

Namun terdapat fenomena dimana setelah infrastruktur menjadi fokus pembangunan (tahun 2015-2019), laba perusahaan sub sektor building construction non BUMN mengalami penurunan yang drastis dibandingkan dengan tren laba bersih perusahaan sub sektor building construction BUMN (Gambar 2). Berdasarkan hasil olah data terhadap laba perusahaan sub sektor building construction (Gambar 2), semua perusahaan non BUMN mengalami kenaikan laba dari tahun 2011 hingga tahun 2014, namun di tahun 2015 laba PT Acset Indonusa Tbk (ACST), PT Nusa Konstruksi Enjiniring Tbk (DGIK), dan PT Nusa Raya Cipta Tbk (NRCA) mengalami penurunan yang drastis. PT Total Bangun Persada (TOTL) sempat mengalami kenaikan laba bersih di tahun 2015 hingga tahun 2017, namun kembali turun pada tahun 2018 dan 2019. Hal ini menunjukkan bahwa kenaikan anggaran dan pembangunan infrastruktur tidak diimbangi dengan laba perusahaan konstruksi milik swasta. Menurut catatan Gabungan Pelaksana Konstruksi Nasional Indonesia (Gapensi), sebanyak 37.000 perusahaan kontraktor non BUMN mengalami kebangkrutan terhitung sejak tahun 2015-2018. Hal ini dinilai dapat memperlambat pemerataan ekonomi nasional (Baderi, 2019); (Uly, 2018).
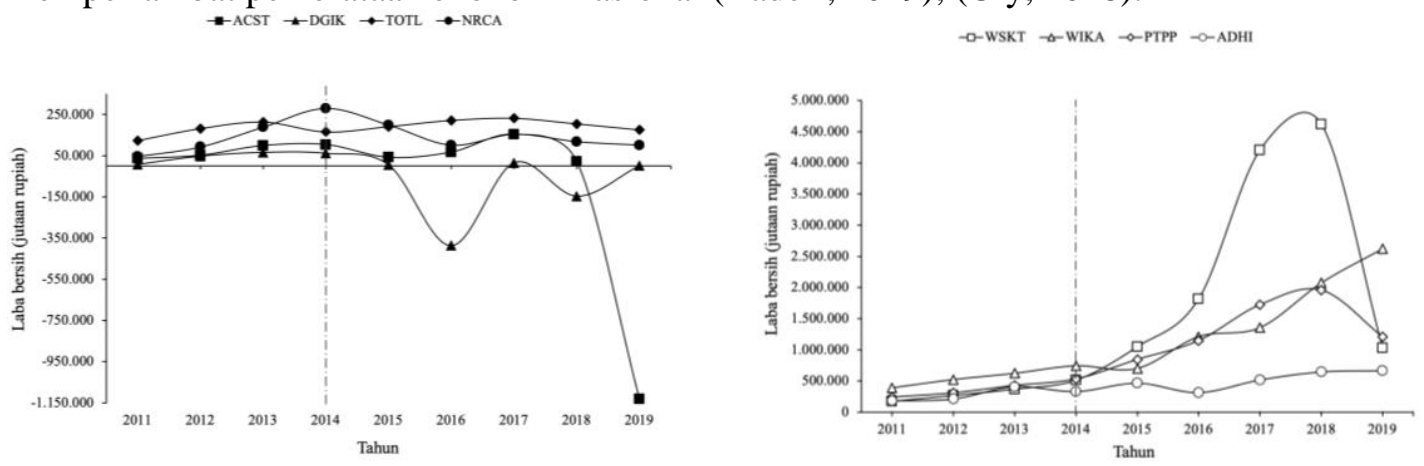

Gambar 2 Laba bersih perusahaan sub sektor building construction non BUMN dan BUMN yang terdaftar di BEI tahun 2011-2019. Perusahaan non BUMN (kiri) dan perusahaan BUMN (kanan)

Studi ini berfokus pada perusahaan sub sektor building construction non BUMN yang terdaftar di Bursa Efek Indonesia periode 2011-2019. Tujuan dari penelitian ini adalah untuk mengukur kinerja keuangan sub sektor building construction non BUMN dengan menggunakan analisis rasio keuangan dan meneliti perbedaan kinerja antara periode sebelum dan setelah infrastruktur menjadi fokus 
pembangunan. Hasil dari penelitian ini akan memudahkan mahasiswa dan sivitas akademika untuk menilai kinerja keuangan perusahaan dan menjadikan pembelajaran lebih praktis dan dipahami. Studi ini juga akan bermanfaat bagi manajer perusahaan untuk mengevaluasi kinerja keuangan perusahaan sebelum mengambil keputusan.

\section{KAJIAN PUSTAKA DAN PENGEMBANGAN HIPOTESIS}

Kinerja keuangan dapat menjadi ukuran keberhasilan suatu perusahaan pada periode tertentu. Kinerja keuangan perusahaan tercermin dalam laporan keuangan dalam bentuk neraca, perhitungan laba-rugi, dan laporan posisi perpindahan modal (Sawir, 2000). Pengukuran kinerja keuangan bertujuan untuk mengevaluasi efisiensi dan efektivitas perusahaan dalam memperoleh laba dan posisi kas tertentu yang dilakukan dalam suatu usaha formal (Hery, 2015). Menurut Horne \& Wachowicz (1998), kinerja keuangan merupakan ukuran prestasi perusahaan maka keuntungan adalah salah satu alat yang digunakan oleh para manajer.

Laporan keuangan adalah informasi yang disiapkan oleh perusahaan untuk pihak yang berkepentingan dengan standar kuangan yang berlaku untuk membantu stakeholders dalam membuat keputusan (Dinarjito, 2018). Laporan keuangan (financial statements) adalah produk akhir yang dihasilkan dari proses pencatatan dan pengikhtisaran transaksi bisnis (Hery, 2015). Laporan neraca keuangan merupakan laporan yang menunjukkan posisi keuangan perusahaan pada periode tertentu (Kurniyanto, 2019). Posisi keuangan dimaksudkan adalah posisi dari sisi aktiva (harta) dan passive (kewajiban dan ekuitas) suatu perusahaan. Neraca memberikan informasi mengenai sumber dan penggunaan dana perusahaan. Neraca aktiva merupakan sisi penggunaan dana perusahaan, sedangkan neraca passiva menunjukkan sumber-sumber dana untuk membiayai investasi tersebut, baik sumber jangka panjang maupun jangka pendek (Sawir, 2000). Contoh rasio-rasio neraca adalah current ratio, total asset ratio dan lain sebagainya (Riyanto, 1995).

Laporan laba-rugi (income statement) merupakan laporan yang menunjukkan jumlah pendapatan yang diperoleh dan biaya-biaya yang dikeluarkan dalam suatu periode tertentu (Kurniyanto, 2019). Laporan perubahan posisi keuangan adalah laporan yang memiliki peranan dalam memberikan informasi mengenai berapa besar dan kemana saja dana dialokasikan serta dari mana sumber dana tersebut diambil. Dengan demikian, laporan sumber dan penggunaan dana akan dapat menjawab pertanyaan, apa yang telah dilakukan perusahaan dengan dana yang dimilikinya. Informasi yang diperoleh dari laporan ini dapat menunjukkan apakah perusahaan sedang maju atau akan mengalami kesulitan keuangan (Sawir, 2000).

Dasar laporan keuangan yang berupa neraca, laporan laba-rugi, dan laporan perubahan posisi keuangan mencerminkan kinerja keuangan perusahaan dilihat dari rasio-rasio keuangan, diantaranya rasio likuiditas, leverage, profitabilitas, dan aktivitas. Rasio keuangan dapat digunakan untuk membandingkan perbedaan kinerja keuangan beberapa perusahaan dalam industri yang sama, perbedaan antar industri, dan membandingkan kinerja keuangan perusahaan dalam periode yang berbeda (Weston \& Copeland, 1995). Menurut (Sawir, 2000), ada 4 rasio terbesar dalam rasio-rasio keuangan, yaitu rasio likuiditas, rasio solvabilitas, rasio profitabilitas, dan rasio aktivitas.

\section{Rasio Likuiditas}

Menurut Wild et al. (2005), likuiditas merupakan kemampuan untuk mengubah aktiva menjadi kas atau kemampuan untuk memperoleh kas dan kemampuan perusahaan untuk memenuhi kebutuhan jangka pendeknya. Likuiditas merupakan salah satu faktor yang dapat mempengaruhi tingkat profitabilitas (Eksandy \& Dewi, 2018). Likuiditas yaitu kemampuan perusahaan untuk memenuhi kewajiban keuangannya yang harus dipenuhi segera mungkin (Oktavianti \& Kurnia, 2018). Likuiditas yang kurang baik dapat menyebabkan kerugian perusahaan (Azizah, 2020). Dalam penelitian ini likuiditas diproksikan dengan current ratio (CR). CR mampu mengukur kemampuan keuangan jangka pendek perusahaan, sehingga dapat menunjukkan tingkat kestabilan perusahaan sub sektor building construction non BUMN. Semakin tinggi nilai CR (lebih dari 1 kali), maka semakin stabil perusahaan. Semakin rendah nilai CR maka perusahaan memiliki resiko dalam likuiditas. Namun pada umumnya, jika nilai CR lebih dari 3 kali, maka dapat dinilai bahwa perusahaan tidak mampu mengelola asetnya dengan baik. Adapun CR dihitung berdasarkan rumus sebagai berikut:

$$
C R=\frac{\text { Aset Lancar }}{\text { Utang Lancar }} \times 100 \%
$$




\section{Rasio Profitabilitas}

Profitabilitas memiliki arti penting bagi perusahaan karena merupakan salah satu dasar penilaian kondisi suatu perusahaan (Putra \& Badjra, 2015). Tingkat profitabilitas perusahaan merupakan ukuran kemampuan perusahaan untuk memperoleh keuntungan dari kegiatan operasional sehari-hari (Putra \& Badjra, 2015). Dalam mengukur tingkat profitabilitas, salah satu indikator yang dapat digunakan yaitu ROA (Stiawan, 2009). Salah satu alat ukur profitabilitas adalah ROA, yang juga merupakan indikator penting dalam menilai kinerja keuangan sebuah perusahaan dari segi investor (Eksandy \& Dewi, 2018). ROA dapat menunjukkan kinerja perusahaan yang dilihat dari penggunaan keseluruhan aset perusahaan dalam menghasilkan keuntungan (Putra \& Badjra, 2015). ROA dihitung berdasarkan rumus sebagai berikut:

\section{Rasio Solvabilitas}

$$
R O A=\frac{\text { Laba Bersih }}{\text { Total Aset }} \quad x 100 \%
$$

Pemilihan struktur keuangan merupakan masalah yang menyangkut komposisi pendanaan yang akan digunakan oleh perusahaan, yang pada akhirnya berarti penentuan berapa banyak utang atau leverage keuangan yang akan digunakan oleh perusahaan untuk mendanai aktivanya. Rasio leverage mengukur tingkat solvabilitas satu perusahaan. Rasio leverage yang umum digunakan adalah debt to equity ratio (DER), rasio ini menggambarkan perbandingan antara total utang dan total ekuitas dalam pendanaan perusahaan dan menunjukkan kemampuan modal mandiri perusahaan tersebut dalam memenuhi seluruh kewajibannya. Leverage adalah kemampuan perusahaan untuk memenuhi semua kewajibannya baik kewajiban jangka panjang maupun jangka pendek (Alfian, 2016). Tingkat leverage menunjukkan kemampuan perusahaan untuk menyelesaikan seluruh kewajibannya kepada pihak lain (Santioso \& Chandra, 2012). DER dihitung berdasarkan rumus sebagai berikut:

$$
D E R=\frac{\text { Total Utang }}{\text { Total Ekuitas }} \times 100 \%
$$

\section{Rasio Aktivitas}

Rasio aktivitas mengukur seberapa efektif perusahaan memanfaatkan sumber daya yang ada pada pengendaliannya. Semua rasio aktivitas ini melibatkan perbandingan antara tingkat penjualan dan investasi pada berbagai jenis aktiva. Rasio-rasio aktivitas menganggap bahwa sebaiknya terdapat keseimbangan yang layak antara penjualan dan berbagai unsur aktiva, yaitu persediaan, piutang, aktiva tetap, dan aktiva lancar (Sawir, 2000). Rasio aktivitas yang digunakan dalam penelitian ini adalah total asset turn over ratio (TATO). TATO digunakan agar dapat mengukur seberapa efisien perusahaan sub sektor building construction non BUMN dalam mengelola aset baik jangka pendek maupun jangka panjang dalam menghasilkan pendapatan. Semakin tinggi nilai TATO, berarti semakin baik perusahaan dalam mengelola asetnya. Semakin rendah nilai TATO, berarti perusahaan kurang optimal dalam menggunakan asetnya. TATO dihitung berdasarkan rumus sebagai berikut:

$$
\text { TATO }=\frac{\text { Pendapatan }}{\text { Total Aset }}
$$

Model penelitian ini diadaptasi dari penelitian sebelumnya yang dilakukan oleh Daryanto \& Nurfadilah (2018), Suryani \& Nasri (2020), Nugeraha et al. (2016). Kerangka berikut (Gambar 3) menjelaskan proses pengukuran kinerja keuangan dan menelaah perbedaan antara kinerja sub sektor building construction non BUMN sebelum dan setelah infrastruktur menjadi fokus pembangunan. 


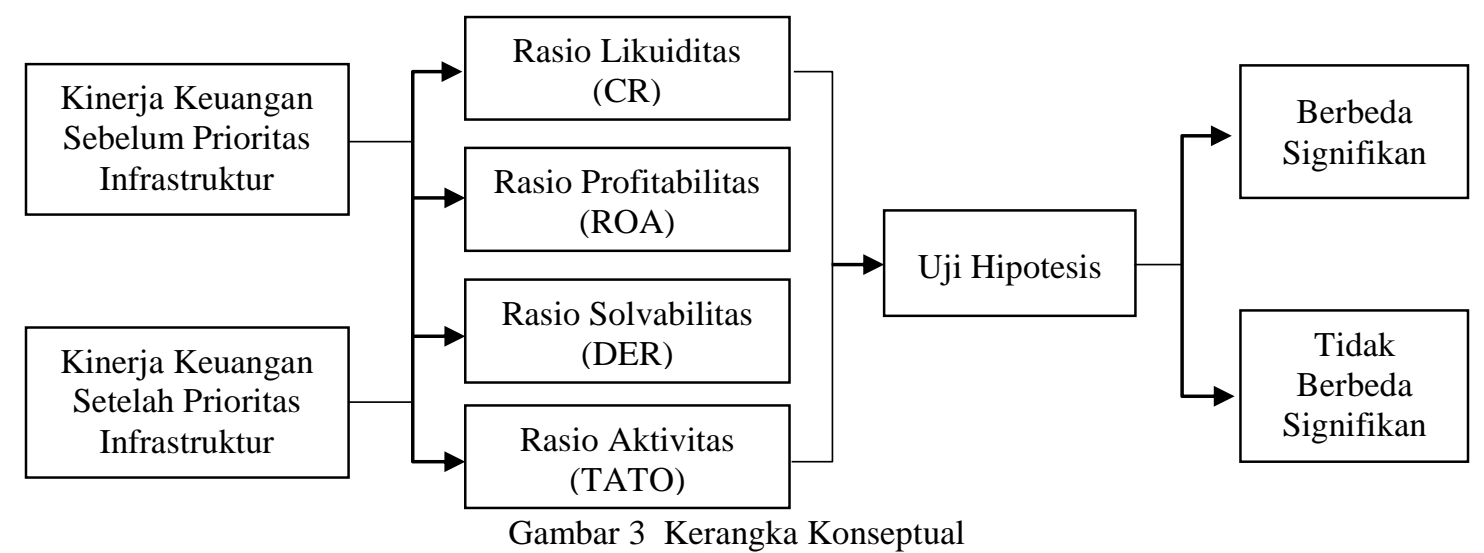

\section{Hipotesis:}

Kasmir (2015) mengemukakan bahwa current ratio (CR) merupakan rasio untuk mengukur kemampuan perusahaan dalam membayar kewajiban jangka pendek atau hutang yang segera jatuh tempo pada saat ditagih secara keseluruhan. Dengan kata lain, berapa banyak aset lancar yang tersedia untuk menutupi kewajiban jangka pendek yang segera jatuh tempo. Jika hasil perhitungan CR rendah, maka dapat dikatakan bahwa perusahaan kurang modal untuk membayar hutang. Namun jika hasil perhitungan CR tinggi, belum tentu kondisi perusahaan sedang baik.

H1: Berdasarkan CR, terdapat perbedaan signifikan pada kinerja keuangan sub sektor building construction non BUMN sebelum dan setelah sektor infrastruktur menjadi fokus pembangunan.

Menurut (Hery, 2015) return on asset (ROA) merupakan rasio yang menunjukkan hasil (return) atas penggunaan aset perusahaan dalam menghasilkan laba bersih. Dengan kata lain, rasio ini digunakan untuk mengukur seberapa besar jumlah laba bersih yang dihasilkan dari setiap dana yang tertanam dalam total aset. Jika ROA semakin tinggi maka semakin tinggi pula jumlah laba bersih yang akan dihasilkan dari setiap rupiah dana atau modal yang ditanamkan kedalam aset perusahaan, sebaliknya semakin rendah ROA maka semakin rendah pula jumlah laba bersih yang dihasilkan dari setiap dana atau modal yang ditanamkan ke dalam aset perusahaan.

$\mathrm{H} 2$ : Berdasarkan ROA, terdapat perbedaan signifikan pada kinerja keuangan sub sektor building construction non BUMN sebelum dan setelah sektor infrastruktur menjadi fokus pembangunan

Kasmir (2015) mengemukakan bahwa debt to equity ratio (DER) merupakan rasio yang digunakan untuk menilai perbandingan hutang dengan ekuitas. Rasio ini diperoleh dengan cara membandingkan antara seluruh hutang, termasuk hutang lancar dengan seluruh ekuitas. DER bertujuan untuk mengetahui jumlah dana yang diperoleh dari peminjam (kreditor dengan pemilik perusahaan). Jika hasil perhitungan DER tinggi menunjukkan bahwa pendanaan dengan hutang semakin banyak, maka perusahaan semakin sulit untuk memperoleh tambahan pinjaman karena dikhawatirkan perusahaan tidak mampu menutupi hutang-hutangnya dengan ekuitas yang dimilikinya.

H3: Berdasarkan total DER, terdapat perbedaan signifikan pada kinerja keuangan sub sektor building construction non BUMN sebelum dan setelah sektor infrastruktur menjadi fokus pembangunan

Kasmir (2015) mengemukakan bahwa total asset turnover (TATO) merupakan rasio yang digunakan untuk mengukur perputaran seluruh aset yang dimiliki perusahaan. Dengan kata lain, TATO digunakan dalam mengukur berapa jumlah penjualan yang diperoleh dari tiap aset yang dimiliki perusahaan. Jika nilai TATO tinggi maka dapat dikatakan bahwa kinerja keuangan perusahaan tersebut baik, karena menunjukkan perusahaan efisien dalam menggunakan asetnya untuk memperoleh pendapatan. Namun jika nilai TATO rendah maka dapat dikatakan bahwa kinerja keuangan perusahaan tersebut kurang baik, karena menunjukkan perusahaan tidak efisien dalam mengelola asetnya untuk menghasilkan pendapatan.

H4: Berdasarkan TATO, terdapat perbedaan signifikan pada kinerja keuangan sub sektor building construction non BUMN sebelum dan setelah sektor infrastruktur menjadi fokus pembangunan. 


\section{METODE PENELITIAN}

Penelitian ini menggunakan analisis rasio keuangan deskriptif yang digunakan untuk mengukur, mendeskripsikan dan menganalisis kinerja keuangan perusahaan sub sektor building construction di BEI selama periode 2011-2019. Pemilihan sampel dilakukan secara purposive sampling dengan kriteria yaitu perusahaan sub sektor building construction milik non BUMN yang terdaftar di BEI dan memiliki data laporan keuangan yang lengkap dari tahun 2011 sampai dengan 2019. Paired sample t-test digunakan untuk menguji signifikansi perbedaan antara periode sebelum (2011-2014) dan setelah infrastruktur menjadi fokus pembangunan (2015-2019). Paired sample t-test adalah teknik statistik yang digunakan dalam penelitian sebelum dan setelah periode tertentu dan digunakan untuk membandingkan dua mean populasi. Perusahaan sub sektor building construction non BUMN dipilih karena adanya fenomena penurunan profitabilitas dan banyaknya perusahaan building construction non BUMN yang gulung tikar setelah infrastruktur menjadi fokus pembangunan. Penelitian ini menggunakan data sekunder berupa laporan keuangan tahunan perusahaan sub sektor building construction yang terdapat pada laman idx.co.id dari tahun 2011 sampai 2019. Indikator kinerja keuangan yang diamati terdiri dari rasio likuiditas, rasio profitabilitas, rasio solvabilitas, dan rasio aktivitas.

\section{HASIL DAN PEMBAHASAN}

\section{Rasio Likuiditas}

Gambar 4 memberikan informasi mengenai persentase dari current ratio (CR) rata-rata pada perusahaan sub sektor building construction non BUMN dari tahun 2011 hingga tahun 2019. Secara keseluruhan, persentase CR meningkat secara fluktuatif dari 156,41\% dari tahun 2011 hingga menjadi $164,26 \%$ di tahun 2019. Rata-rata CR pada periode sebelum infrastruktur menjadi fokus pembangunan (2011-2014) adalah 155,92\%. Sedangkan rata-rata CR pada periode setelah infrastruktur menjadi fokus pembangunan (2015-2019) adalah $168,50 \%$. Artinya rata-rata CR mengalami peningkatan setelah infrastruktur menjadi fokus pembangunan. Secara keseluruhan, rata-rata CR selama sembilan tahun terakhir (2011-2019) adalah 163,64\%. Artinya setiap Rp. 1 kewajiban lancar dijamin dengan Rp.1,6364 dari aset lancar. Jadi secara keseluruhan, perusahaan sub sektor building construction non BUMN memiliki kemampuan untuk memenuhi kewajiban lancarnya dengan menggunakan aset lancar yang dimiliki perusahaan. Dengan persentase sebesar 163,64\% atau 1,64 kali (lebih besar dari 1), menunjukkan bahwa rata-rata perusahaan memiliki likuiditas yang cukup ideal.

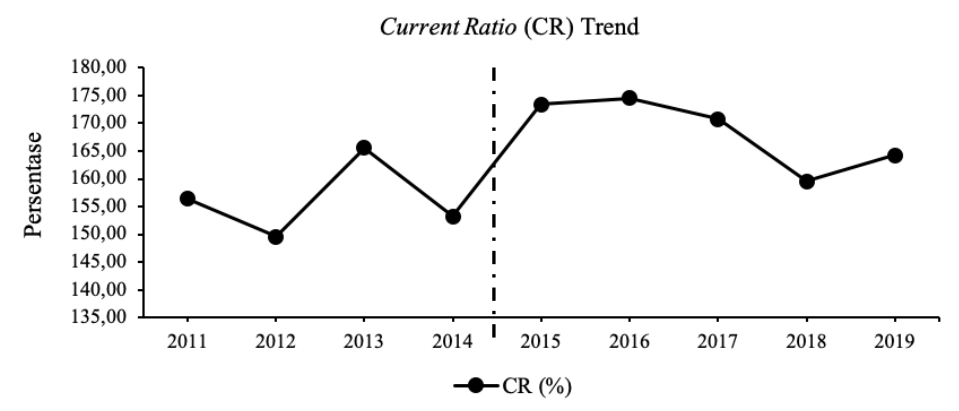

Gambar 4 Trend rata-rata current ratio (CR) perusahaan non BUMN tahun 2011-2019

\section{Rasio Profitabilitas}

Gambar 5 dibawah ini memberikan informasi mengenai persentase dari return on assets (ROA) rata-rata pada perusahaan sub sektor building construction non BUMN dari tahun 2011 hingga tahun 2019. Secara keseluruhan, persentase ROA perusahaan non BUMN menurun secara fluktuatif dari 6,62\% di tahun 2011 hingga menjadi $-0,38 \%$ di tahun 2019. Rata-rata ROA pada periode sebelum infrastruktur menjadi fokus pembangunan (2011-2014) adalah 8,93\%. Sedangkan rata-rata ROA pada periode setelah infrastruktur menjadi fokus pembangunan (2015-2019) adalah 2,79\%. Artinya rata-rata ROA pada perusahaan non BUMN mengalami penurunan setelah infrastruktur menjadi fokus pembangunan. Secara keseluruhan, rata-rata ROA selama sembilan tahun terakhir (2011-2019) adalah $5,16 \%$. Artinya, secara keseluruhan rata-rata perusahaan sub sektor building construction non BUMN belum efektif dalam mengelola asetnya untuk menghasilkan jumlah laba bersih yang lebih besar. 


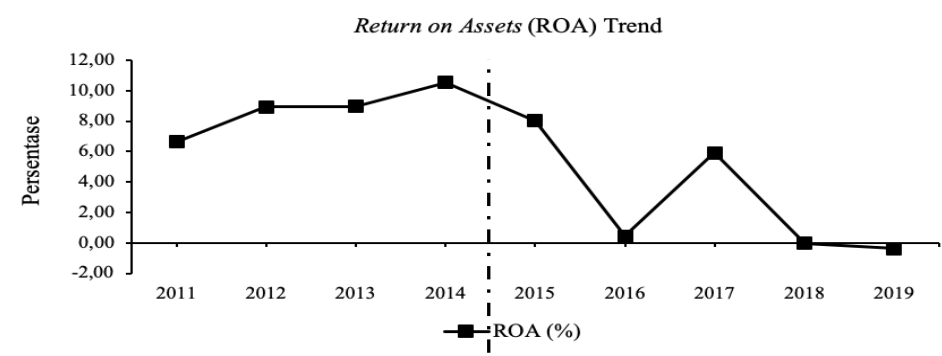

Gambar 5 Trend rata-rata return on assets (ROA) perusahaan non BUMN tahun 2011-2019

\section{Rasio Solvabilitas}

Gambar 6 dibawah ini memberikan informasi mengenai persentase dari debt to equity ratio (DER) rata-rata pada perusahaan sub sektor building construction non BUMN dari tahun 2011 hingga tahun 2019. Secara keseluruhan, persentase DER meningkat secara fluktuatif dari 160,61\% di tahun 2011 hingga menjadi 612,67\% di tahun 2019. Rata-rata DER pada periode sebelum infrastruktur menjadi fokus pembangunan (2011-2014) adalah 144,56\%. Sedangkan rata-rata DER pada periode setelah infrastruktur menjadi fokus pembangunan (2015-2019) adalah 232,94\%. Rata-rata DER pada perusahaan non BUMN cukup stabil dari tahun 2011-2018, namun mengalami kenaikan yang drastis di tahun 2019. Secara keseluruhan, rata-rata DER selama sembilan tahun terakhir (2011-2019) adalah 198,83\%. Artinya, rata-rata perusahaan sub sektor building construction non BUMN memiliki jumlah kewajiban (utang) yang lebih besar dari jumlah ekuitas nya sebanyak 1,99 kali. Hal ini menunjukkan bahwa kemampuan perusahaan dalam memenuhi kewajibannnya dengan ekuitas, dinilai kurang baik karena adanya kenaikan DER yang drastis di tahun 2019.

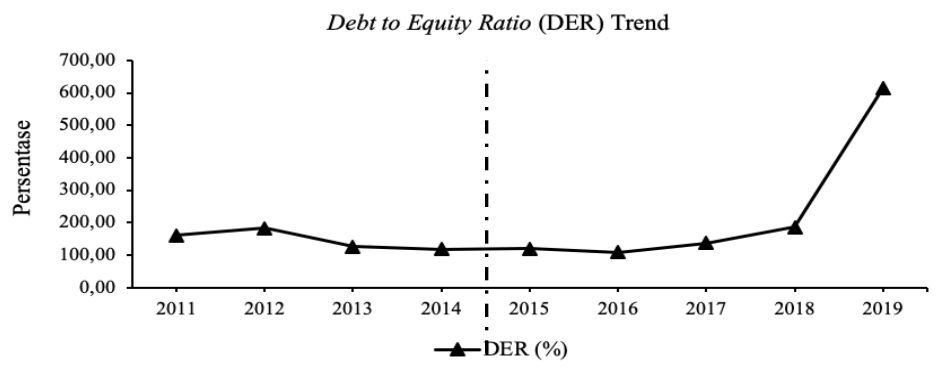

Gambar 6 Trend rata-rata debt to equity ratio (DER) perusahaan non BUMN tahun 2011-2019

\section{Rasio Aktivitas}

Gambar 7 dibawah ini memberikan informasi mengenai persentase dari total assets turnover (TATO) rata-rata pada perusahaan sub sektor building construction non BUMN dari tahun 2011 hingga tahun 2019. Secara keseluruhan, persentase TATO menurun secara fluktuatif dari 1,19 kali di tahun 2011 hingga menjadi 0,72 kali di tahun 2019. Rata-rata TATO pada periode sebelum infrastruktur menjadi fokus pembangunan (2011-2014) adalah 1,14 kali. Sedangkan rata-rata TATO pada periode setelah infrastruktur menjadi fokus pembangunan (2015-2019) adalah 0,80 kali. Artinya rata-rata TATO pada perusahaan non BUMN mengalami penurunan setelah infrastruktur menjadi fokus pembangunan. Secara keseluruhan, rata-rata TATO selama sembilan tahun terakhir (2011-2019) adalah 0,93 kali. Artinya, rata-rata perusahaan sub sektor building construction milik non BUMN memiliki penjualan (pendapatan) sebanyak 0,93 kali atau 93\% dari total aset yang dimiliki.

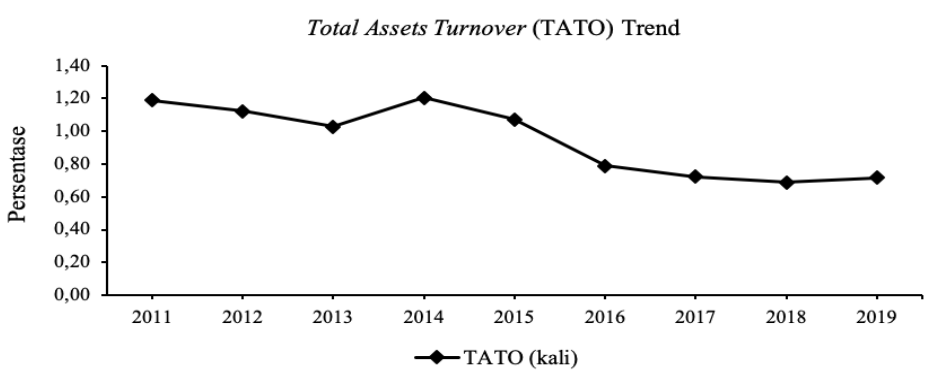

Gambar 7 Trend rata-rata total assets turnover (TATO) perusahaan non BUMN tahun 2011-2019 
Uji normalitas dilakukan untuk mengetahui apakah data berdistribusi normal atau tidak. Berikut merupakan hasil uji normalitas dilakukan dengan uji Kolmogorov-Smirnov terhadap perusahaan sub sektor building construction non BUMN pada periode sebelum dan setelah infrastruktur menjadi fokus pembangunan, yang disajikan pada Tabel 2 .

Tabel 2 Hasil uji normalitas

\begin{tabular}{llllc}
\hline \multicolumn{1}{c}{ Indikator } & Periode & Sig. & $\alpha$ & Kesimpulan \\
\hline Current Ratio (CR) & sebelum &, $200^{*}$ & 0,05 & Berdistribusi normal \\
& setelah &, $200^{*}$ & 0,05 & Berdistribusi normal \\
Return on Assets (ROA) & sebelum &, $200^{*}$ & 0,05 & Berdistribusi normal \\
& setelah &, $200^{*}$ & 0,05 & Berdistribusi normal \\
\multirow{3}{*}{ Debt to Equity Ratio (DER) } & sebelum &, $200^{*}$ & 0,05 & Berdistribusi normal \\
& setelah &, 002 & 0,05 & Berdistribusi tidak normal \\
& sebelum &, 097 & 0,05 & Berdistribusi normal \\
& setelah &, $200^{*}$ & 0,05 & Berdistribusi normal \\
\hline
\end{tabular}

Sumber: data diolah 2020

Hasil uji pada Tabel 2 menunjukkan bahwa seluruh data yang berdistribusi normal (Sig. $>0,05)$ akan diuji dengan paired sample t-test. Sementara DER pada periode setelah infrastruktur menjadi fokus pembangunan, berdistribusi tidak normal (Sig. < 0,05) diuji dengan menggunakan Wilcoxon signed rank test.

Uji beda dilakukan dengan menggunakan paired sample t-test untuk mengetahui signifikansi perbedaan kinerja keuangan perusahaan sub sektor building construction non BUMN pada periode sebelum dan setelah infrastruktur menjadi fokus pembangunan dengan menggunakan empat indikator yaitu current ratio (CR), return on assets (ROA), debt to equity (DER), dan total assets turnover (TATO). Adapun rekapitulasi hasil uji beda disajikan pada Tabel 3.

Uji hipotesis pertama menghasilkan nilai Sig. (2-tailed) yang menunjukkan angka lebih besar dari signifikansi $0,05(0,457>0,05)$. Dapat diartikan bahwa berdasarkan current ratio $(\mathrm{CR})$, tidak terdapat perbedaan signifikan pada kinerja keuangan sub sektor building construction non BUMN sebelum dan setelah sektor infrastruktur menjadi fokus pembangunan. Hal ini dapat terjadi karena kenaikan rata-rata CR pada tahun 2015 dan 2016 diimbangi dengan penurunan rata-rata CR di tahun 2017 dan 2018. Penurunan CR terjadi karena adanya penurunan aset lancar akibat pengurangan pada piutang atas penjualan investasi. Selain itu adanya kenaikan jumlah hutang lancar karena adanya pertambahan utang bank jangka pendek. Meskipun demikian penurunan rata-rata CR yang terjadi tidak lebih besar dari kenaikannya, sehingga perbedaan rata-rata CR antara sebelum dan setelah sektor infrastruktur menjadi fokus pembangunan tidak signifikan. Namun pada situasi ini perusahaan harus dapat memastikan profil jatuh tempo antara aset dan utang perusahaan, dan mengelola penerimaan tagihan yang tepat waktu untuk mengurangi risiko likuiditas.

Uji hipotesis kedua menghasilkan nilai Sig. (2-tailed) yang menunjukkan angka lebih kecil dari signifikansi $0,05(0,002<0,05)$. Dapat diartikan bahwa berdasarkan retun on assets (ROA), terdapat perbedaan signifikan pada kinerja keuangan sub sektor building construction non BUMN sebelum dan setelah sektor infrastruktur menjadi fokus pembangunan. Penurunan rata-rata ROA dari 10,59\% menjadi 2,79\% menunjukkan adanya penurunan profitabilitas perusahaan setelah infrastruktur menjadi fokus pembangunan. Berdasarkan analisa terhadap laporan keuangan masing-masing perusahaan sub sektor building construction non BUMN, hal ini disebabkan oleh beberapa faktor yang dapat mengurangi profitabilitas, seperti rendahnya laba tahun berjalan dan pendapatan bersih yang diterima, besarnya beban pokok penjualan, beban penjualan, dan biaya keuangan berupa bunga pinjaman bank, serta adanya pelanggan yang tidak membayar sebagian atau seluruh piutang atau tidak membayar secara tepat waktu yang menyebabkan kerugian perusahaan. Piutang usaha lebih dari satu tahun juga menjadi salah satu penyebab rendahnya profitabilitas, karena perseroan harus membentuk cadangan penurunan nilai piutang yang besar atas potensi tidak tertagihnya piutang. Hal ini memberikan implikasi kepada perusahaan sub sektor building construction non BUMN agar dapat melakukan penagihan piutang secara berkala. Perusahaan dapat melakukan antisipasi risiko pembayaran melalui pemilihan klien dan memastikan materi isi kontrak yang aman. Perusahaan juga dapat melakukan penelaahan berkala terhadap dampak atas pinjaman dan senantiasa menjaga komposisi pendanaan sesuai kebutuhan. 
Tabel 3 Paired sample t-test

\begin{tabular}{|c|c|c|c|c|c|c|}
\hline Hipotesis & Indikator & Periode & Means & $\begin{array}{c}\text { Paired } \\
\text { sample t- } \\
\text { test (Sig.) }\end{array}$ & $\begin{array}{c}\text { Wilcoxon } \\
\text { signed rank } \\
\text { (Sig.) }\end{array}$ & Keterangan \\
\hline$H_{l}$ & $\begin{array}{l}\text { Current Ratio } \\
\text { (CR) }\end{array}$ & $\begin{array}{l}\text { Sebelum } \\
\text { Setelah }\end{array}$ & $\begin{array}{l}153.0057 \\
168.4971 \\
\end{array}$ & .457 & - & $\begin{array}{r}\text { Tidak berbeda } \\
\text { signifikan } \\
\end{array}$ \\
\hline $\mathrm{H}_{2}$ & $\begin{array}{l}\text { Return on Assets } \\
\text { (ROA) }\end{array}$ & $\begin{array}{l}\text { Sebelum } \\
\text { Setelah }\end{array}$ & $\begin{array}{r}10.5914 \\
2.7914 \\
\end{array}$ & .002 & - & $\begin{array}{r}\text { Berbeda } \\
\text { signifikan } \\
\end{array}$ \\
\hline$H_{3}$ & $\begin{array}{l}\text { Debt to Equity } \\
\text { Ratio (DER) } \\
\end{array}$ & $\begin{array}{l}\text { Sebelum } \\
\text { Setelah }\end{array}$ & & - & .866 & $\begin{array}{r}\text { Tidak berbeda } \\
\text { signifikan } \\
\end{array}$ \\
\hline$H_{4}$ & $\begin{array}{l}\text { Total Assets } \\
\text { Turnover } \\
\text { (TATO) }\end{array}$ & $\begin{array}{l}\text { Sebelum } \\
\text { Setelah }\end{array}$ & $\begin{array}{r}1.2343 \\
.7986\end{array}$ & .010 & & $\begin{array}{r}\text { Berbeda } \\
\text { signifikan }\end{array}$ \\
\hline
\end{tabular}

Uji hipotesis ketiga adalah untuk menguji apakah berdasarkan debt to equity ratio (DER) terdapat perbedaan signifikan pada kinerja keuangan sub sektor building construction non BUMN sebelum dan setelah sektor infrastruktur menjadi fokus pembangunan. Berdasarkan nilai Sig. (2-tailed) pada $\mathrm{H}_{3}$ yang bernilai 0,866 (> 0,05). Dapat diartikan bahwa berdasarkan debt to equity ratio (DER), tidak terdapat perbedaan signifikan pada kinerja keuangan sub sektor building construction non BUMN sebelum dan setelah sektor infrastruktur menjadi fokus pembangunan. Hal ini dapat terjadi karena nilai rata-rata DER dari tahun 2011 hingga 2018 cukup stabil. Kecuali di tahun 2019, nilai rata-rata DER meningkat drastis diantaranya karena adanya tambahan pinjaman dari pemegang saham, pinjaman pihak ketiga serta adanya selilih kurs dari penjabaran laporan keuangan. Namun kenaikan rata-rata DER di tahun 2019 ini tidak merubah nilai rata-rata DER periode 2015-2019 secara berarti. Sehingga perbedaan rata-rata DER antara sebelum dan setelah sektor infrastruktur menjadi fokus pembangunan tidak signifikan.

Uji hipotesis keempat adalah untuk menguji apakah berdasarkan total assets turnover (TATO), terdapat perbedaan signifikan pada kinerja keuangan sub sektor building construction non BUMN sebelum dan setelah sektor infrastruktur menjadi fokus pembangunan. Berdasarkan nilai Sig. (2-tailed) pada $\mathrm{H}_{4}$ yang menunjukkan angka lebih kecil dari signifikansi $0,05(0,01<0,05)$, maka $\mathrm{H}_{4}$ diterima. Artinya, berdasarkan total assets turnover (TATO), terdapat perbedaan signifikan pada kinerja keuangan sub sektor building construction non BUMN sebelum dan setelah sektor infrastruktur menjadi fokus pembangunan. TATO mengalami penurunan dari 1,23 kali menjadi 0,80 kali pada periode setelah infrastruktur menjadi fokus pembangunan. Berdasarkan analisa terhadap laporan keuangan masingmasing perusahaan sub sektor building construction non BUMN, hal ini terjadi terkait dengan jumlah pendapatan yang diterima, dan lama waktu penagihan piutang terutama pada piutang usaha yang lebih dari satu tahun. Nilai TATO yang lebih kecil menunjukkan bahwa jumlah pendapatan lebih kecil dari total aset. Aset terdiri dari dua yaitu aset lancar dan aset tidak lancar. Aset lancar terdiri dari kas, surat berharga, persediaan, dan piutang. Hal ini membuktikan bahwa besarnya piutang yang belum terbayarkan akan memperbesar jumlah aset dibandingkan dengan pendapatannya, sehingga TATO menurun. Hal ini memberikan implikasi kepada perusahaan agar dapat mengoptimalisasi penggunaan aset dalam menghasilkan pendapatan dan segera melakukan penagihan piutang perusahaan.

\section{KESIMPULAN}

Dalam penelitian ini ditemukan bahwa terdapat perbedaan signifikan pada return on assets (ROA) antara periode sebelum dan setelah infrastruktur menjadi fokus pembangunan. Hasil ini mengimplikasikan bahwa adanya penurunan kemampuan perusahaan dalam menghasilkan laba. Adapun saran kepada manajer perusahaan sub sektor building construction non BUMN agar dapat melakukan penagihan piutang secara berkala. Perusahaan dapat melakukan antisipasi risiko pembayaran melalui pemilihan klien dan memastikan materi isi kontrak yang aman. Perusahaan juga dapat melakukan penelaahan berkala terhadap dampak atas pinjaman dan senantiasa menjaga komposisi pendanaan sesuai kebutuhan.

Berdasarkan analisis rasio aktivitas, terdapat perbedaan signifikan pada total assets turnover (TATO) antara periode sebelum dan setelah infrastruktur menjadi fokus pembangunan. Hasil ini mengimplikasikan bahwa bahwa perusahaan sub sektor building construction non BUMN memiliki besarnya piutang yang belum terbayarkan dibandingkan dengan pendapatannya. Adapun saran kepada 
manajer perusahaan sub sektor building construction non BUMN agar dapat mengoptimalisasi penggunaan aset dalam menghasilkan pendapatan dan segera melakukan penagihan piutang perusahaan.

Adapun keterbatasan penelitian ini yang belum bisa mengukur praktik proyek konstruksi dari dampak adanya prioritas infrastruktur secara terperinci. Sehingga penelitian selanjutnya disarankan untuk melakukan analisis lebih lanjut dengan mempertimbangkan pemetaan proyek konstruksi sebagai dampak dari prioritas infrastruktur.

\section{SARAN}

Adapun saran praktis dari hasil penelitian ini yaitu kepada manajer perusahaan sub sektor building construction non BUMN agar dapat melakukan penagihan piutang secara berkala. Perusahaan dapat melakukan antisipasi risiko pembayaran melalui pemilihan klien dan memastikan materi isi kontrak yang aman. Perusahaan juga dapat melakukan penelaahan berkala terhadap dampak atas pinjaman dan senantiasa menjaga komposisi pendanaan sesuai kebutuhan.

Sedangkan saran teoritis dari hasil penelitian ini yaitu penelitian selanjutnya agar dapat melakukan analisis lebih lanjut dengan mempertimbangkan pemetaan proyek konstruksi sebagai dampak dari prioritas infrastruktur.

\section{REFERENSI}

Alfian, M. A. (2016). Analisis Pengaruh Faktor yang Menentukan Profitabilitas Sektor Properti, Real Estate, dan Konstruksi Bangunan yang Terdaftar di Bursa Efek Indonesia Periode 2010-2014. Jurnal Ilmu Manajemen, 4(1), 1-14.

Azizah, N. (2020). Pengaruh Kinerja Keuangan dan Makroekonomi Terhadap Harga Saham Sektor Industri Konsumsi di Indonesia. Institut Pertanian Bogor.

Baderi, F. (2019). Ribuan Kontraktor Swasta Bangkrut Akibat Dominasi BUMN Karya. Retrieved July 20, 2020, from https://www.neraca.co.id/article/123028/ribuan-kontraktor-swasta-bangkrutakibat-dominasi-bumn-karya

BPIW. (2016). Infrastruktur PUPR terpadu untuk negeri. Sinergi Kementerian PUPR, pp. 1-62. Retrieved from http://bpiw.pu.go.id/uploads/publication/attachment/Buletin_042017_Edisi16.pdf

BPS. (2018). Statistik Konstruksi 2018. Retrieved from https://www.bps.go.id/website/pdf_publikasi/Statistik-Konstruksi-2014.pdf

Daryanto, W. M., \& Nurfadilah, D. (2018). Financial performance analysis before and after the decline in oil production: Case study in Indonesian oil and gas industry. International Journal of Engineering and Technology(UAE), 7(3), 10-15. https://doi.org/10.14419/ijet.v7i3.21.17085

Dinarjito, A. (2018). Menilai Kesehatan BUMN Konstruksi yang Terdaftar di Bursa Efek Indonesia Sebagai Akibat Meningkatnya Proyek Infrastruktur Pemerintah. Substansi, 2(1), 1-18.

Eksandy, A., \& Dewi, V. M. (2018). Pengaruh Perputaran Modal Kerja , Perputaran Piutang dan Perputaran Kas Terhadap Profitabilitas Perusahaan (Studi Pada Perusahaan Konstruksi Sektor Infrastruktur di Bursa Efek Indonesia Periode 2012 - 2015). Jurnal Dinamika UMT, 2(2), 1-14. https://doi.org/10.31000/dinamika.v2i2.1433

Hery. (2015). Analisis Kinerja Manajemen. Jakarta: Grasindo.

Horne, J., \& Wachowicz, J. (1998). Prinsip-prinsip Manajemen Keuangan. Jakarta: Grasindo.

Jonudin, Nurazi, R., \& Kananlua, P. S. (2011). Analisa Kinerja Keuangan Perusahaan Jasa Konstruksi di Bursa Efek Jakarta. Jurnal Ilmiah Manajemen, 9(1), 13-30.

Kasmir. (2015). Analisis Laporan Keuangan (5th ed.). Jakarta: PT Raja Grafindo Persada.

Kurniyanto, I. (2019). Pengaruh Variabel Kinerja Keuangan dan Variabel Makroekonomi Terhadap Harga Saham Perusahaan Pertanian di Bursa Efek Indonesia. Institut Pertanian Bogor.

Nugeraha, A., Mandra, I. G., \& Putra, I. N. N. A. (2016). Analisis Perbandingan Kinerja Keuangan Sebelum dan Sesudah Diberlakukannya Tax Amnesty Periode Pertama Pada Perusahaan Sub Sektor Property dan Real Estate yang Terdaftar di BEI. Jurnal Ilmu Manajemen Dan Bisnis, $4(1), 1-20$.

Oktavianti, \& Kurnia, S. (2018). Pengaruh Modal Kerja , Likuiditas dan Return on Assets (ROA) Terhadap Kinerja Keuangan Perusahaan Sub Sektor Konstruksi dan Bangunan yang Terdaftar di Bursa Efek Indonesia Tahun 2013-2016. Equilibria, 5(2). 
Putra, A., \& Badjra, I. (2015). Pengaruh Leverage, Pertumbuhan Penjualan dan Ukuran Perusahaan terhadap Profitabilitas. E-Jurnal Manajemen Universitas Udayana, 4(7), 2052-2067.

Rachenjantono, E. (2008). Analisa dan Evaluasi Hukum Tentang Jasa Konstruksi. In Badan Pembinaan Hukum Nasional Departemen Hukum dan Hak Asasi Manusia Republik Indonesia. Retrieved from https://www.bphn.go.id/data/ documents/jasa_konstruksi.pdf

Riyanto, B. (1995). Dasar-dasar Pembelanjaan Perusahaan (4th ed.). Yogyakarta: Yayasan Penerbit Gajah Mada.

Santioso, L., \& Chandra, E. (2012). Pengaruh Profitabilitas, Ukuran Perusahaan, Leverage, Umur Perusahaan, dan Dewan Komisaris Independen Dalam Pengungkapan Corporate Social Responsibility. Jurnal Bisnis Dan Akuntansi, 14(1), 17-30. Retrieved from https://jamal.ub.ac.id/index.php/jamal/article/view/1131

Sawir, A. (2000). Analisis Kinerja Keuangan dan Perencanaan Keuangan Perusahaan (2nd ed.). Jakarta: PT Gramedia Pustaka Utama.

Setjen DPR RI. (2015). Anggaran Pembangunan Infrastruktur Kebutuhan dan Tantangan Tahun 2015. Retrieved from http://www.dpr.go.id/doksetjen/dokumen/apbn_Anggaran_Infrastruktur 20150129103211.pdf

Stiawan. (2009). Analisis Pengaruh Faktor Makroekonomi, Pangsa Pasar Dan Karakteristik Bank Terhadap Profitabilitas Bank Syariah (Studi Bank Syariah Periode 2005-2008). Tesis, 1-100.

Suraji, A., Tamin, R., Wibowo, M., Soeparto, H., Trigunarsyah, B., \& Soemardi, B. (2007). Konstruksi Indonesia 2030 untuk Kenyamanan Lingkungan Terbangun.

Suryani, S. E., \& Nasri, R. (2020). Analisis Perbandingan Kinerja Keuangan Sebelum Dan Sesudah Penerapan E-Commerce. Jurnal Muhammadiyah Manajemen Bisnis, 1(2), 109-118.

Trianto. (2011). Dalam Masalah Penilaian Kesehatan Keuangan Perusahaan.

Uly, Y. (2018). 37000 Kontraktor Swasta Bangkrut dalam 3 Tahun Gara-Gara Tak Dibayar Hingga No Job. Retrieved July 20, 2020, from https://economy.okezone.com/read/2018/03/14/470/1872766/37-000-kontraktor-swastabangkrut-dalam-3-tahun-gara-gara-tak-dibayar-hingga-no-job

Weston, J., \& Copeland, T. (1995). Manajemen Keuangan (8th ed.). Jakarta: Gelora Aksara Pratama. Wild, John, J., Subramanyam, \& RF, H. (2005). Financial Statement Analysis (8th ed.). Jakarta: Salemba 4. 